\title{
Environment Education and Ecological Art Exhibitions Influence Young People's Intention to Consume Plant-Based Food
}

\author{
Dr. Kuei-Chiu Lee \\ Department of Cooperative Economics and Social Entrepreneurship \\ Feng Chia University \\ 100, Wenhwa Rd., Seatwen, Taichung \\ Taiwan 40724
}

\begin{abstract}
For the last 10 years, to save energy and reduce carbon emissions, the Taiwanese government has encouraged citizens to eat plant-based food. This study examines plant-based food consumption by young people after receiving environmental education training and participating in eco-environmental art exhibitions. In the process, the consumption of plant-based food was analyzed from the different dimensions of consumer motivation, including health, religion, environmental protection and fashion. According to the results of the empirical study, while approximately $70 \%$ of young consumers eat meat-based food, over $80 \%$ of young consumers agree that plant-based food is beneficial for health and environmental protection. Moreover, as the Taiwanese government has implemented the Meatless Monday policy in elementary and middle schools for 10 years, most young people agree that eating plant-based food helps reduce carbon emissions and promotes environmental protection. Enhanced environmental education and diverse eco-environmental art exhibitions would strengthen young people's behavioral intention to consume plantbased food. The findings of this study also show that young people do not believe that plant-based food consumption is a religious or moral issue. Young consumers choose plant-based food because they want to protect the earth and the environment. This finding underlines the importance of environment education.
\end{abstract}

Keywords: Environment education, Consumer motivation, Purchase intention, Plant-based food

\section{Introduction}

Concerning economic benefits, reducing global warming should start with reducing the methane caused by the breeding of animals (Huang et al., 2010). According to the report released by the Food and Agriculture Organization of the United Nations (2008), the greenhouse gases generated in the breeding of animals to be consumed as food accounts for $18 \%$ of the total emissions of greenhouse gases across the world, approximately $40 \%$ more than that (13\%) of all transportation modes combined. Andreas Troge, the director of the Environmental Protection Department of Germany, made a public appeal to consumers to eat less meat and exercise more. Turner-McGrievy GM et al.(2015) found the vegan, vegetarian, and pesco-vegetarian participants had significant improvements in their Dietary Inflammatory Index score after 2 months. To support the global Meatless Monday initiative, Taiwan established a similar network platform on September 21, 2009. According to the Meatless Monday initiative, consuming plant-based food can have a substantial impact on the environment. The most efficient way to cool down the earth is to consume more plant-based food is one way to practice environmental conservation (Huang et al., 2010).

In Taiwan, most of the long-term and strict vegetarians consume a plant-based diet for religious reasons. However, many new vegetarians begin eating plant-based diets after learning of the importance of plant-based food for physical and mental health and for ecological environmental protection. Recently, plant-based food has become an influential force in the food consumption market. People have developed increasingly positive attitudes towards plant-based food, and consuming plant-based food has become a lifestyle that transcends location, religion and age. Analyzing consumer motivations from such dimensions as health, religion, environmental protection and fashion, this study investigated the consumption and attitude towards plant-based food through environment education courses and eco-environmental art exhibitions to analyze young people's intention and behavior regarding purchasing plant-based food.

\section{Literature Review}

\subsection{Consumer motivation theory}

Armstrong, Kolter and Opresnik (2017) defined motivation as an inspired desire that urges a person to take action to satisfy his/her want or need. Schleenbecker and Hamm's (2013) suggest that health (including food safety), sensory characteristics (such as taste and freshness), and ethical properties (such as environmental protection and animal welfare) are the most important consumption motives. 
Lindeman and Stark (1999) indicated that vegetarianism was best predicted by ideological food choice motives, such as magical beliefs about food and health, and personal strivings for ecological welfare and for understanding oneself and the world. According to Hawkins, Best and Coney (2004), motivation represents an internal force that cannot be observed and a behavioral reaction; meanwhile, it directs the reaction. Teng and Lu (2016) findings the consumers' consumption motives will influence organic food decisions, but the involvement and consumer will vary in their intention to buy organic foods.

\subsection{Plant-based food and health motivation}

According to the findings of a 12-year study involving 47,150 respondents that was published in the New England Journal of Medicine in 2014, those who consume high amounts of meat in their diet have a higher risk (41\%) of suffering a stroke, and consume a lot of seafood, the risk is $51 \%$ higher. Several empirical studies have demonstrated that seafood and animal-based foods are related to stroke. These studies have also shown that the consumption of large amounts of vegetable protein-based food can reduce the risk of stroke by $27 \%$, correcting the long-held misunderstanding that consuming vegetables with high amounts of purine would result in a stroke (Cheng, 2009).Jeong and Jang (2016) findings that the effect of mental simulation varies depending on health factors. This indicated that the healthy positively influenced attitudes and purchasing intentions. Dr. Kaare Norum, a heart expert, published an article in the Journal of the Norwegian Medical Association. The article was based on an extensive international survey, and the respondents were scientists in different fields who were interested in the problem of atherosclerosis. According to the findings, $99 \%$ of the research fellows confirmed the correlation between diet and heart attack, and they all agreed that the main causes for heart attacks were "too many calories and too much saturated fat and cholesterol" (Timothy, Appleby and Rosell, 2006; Jallinoja et al.,2014;Jessica, 2015). Vainio et al.(2016) point out that dietary changes to include more beans and soy products were motivated by natural concerns, as well as health, social image, and price. The results suggest that food choice motives play an important role in changing towards more sustainable food consumption patterns in which meat/beef is replaced with plant proteins. According to the findings of the study by Juisan Chen from National Taiwan University Hospital: 1) plant-based food does not lead to anemia; 2) vegetarians do not suffer malnutrition, and the test based on the latest electrical flow method also demonstrated that the hemoglobin of vegetarians was completely normal; and 3) the cholesterol of vegetarians is low. The normal cholesterol level of a healthy person is less than $220 \mathrm{mg}$, and a smaller quantity indicates a healthier body. The average cholesterol of vegetarians is $158 \mathrm{mg}$, while that of meat eaters was $180 \mathrm{mg}$.

\subsection{Plant-based food and religion motivation}

The Taiwanese people have faith in the following religions: Buddhism, Taoism, Sciomancy, and Christianity. In Buddhism, there are beliefs in karma and ahimsa; Taoists believe that there is a correlation between plant-based food and immortality and that thus those who want to become immortal and those who are already immortal consume plantbased food. Sciomancy advocates "diet-keeping and ahimsa" in daily life. Its most distinctive feature is "consuming plant-based food," and consuming plant-based food is regarded as a fundamental doctrine (Tu, 2005). According to the Catholic Christian creeds, God sends all vegetables with seeds and all fruits with kernels on the trees to people and encourages them to consume plant-based food (Lu, 2006). In Taiwan, certain Christian sects adopt plant-based food for religious and health reasons.

\subsection{Plant-based food and environmental protection motivation}

Global warming and the rebound effect from greenhouse gas emissions have caused serious destruction to the environment, and the earth has been brought to the brink of havoc. If the environmental problems are solved, it is necessary to start with promoting environment awareness and protection to individuals (Anthony et al.,2007). One of the major causes for the greenhouse effect is animal husbandry, and consuming plant-based food can alleviate the damage caused by animal husbandry and promote environmental conservation.

It has been confirmed by the United States Environmental Protection Agency that the waste from chickens, pigs and cows have polluted 22 rivers (35,000 miles in total), and the underground water in 15 states in the US. (The People for the Ethical Treatment of Animals; PETA, 2001).Relevant academic papers have demonstrated that consuming plantbased food has become an important approach for improving the environment.

\subsection{Plant-based food and fashion motivation}

Kao (2002) regarded plant-based food as a popular culture in Taiwan and listed seven factors that influenced the popularity of the plant-based food culture in Taiwan: (1) religion, (2) Westernization, (3) pursuit of bodybuilding, (4) personal taste, (5) commercial marketing, (6) publicity in the media, and (7) family members and friends (Lin, 2007). The term, "fashion," mentioned in this paper emphasizes the last three factors mentioned above. 
Jallinoja et al. (2016) mentions the increase in plant protein consumption, the future plans to increase bean consumption, and the associations of frequent bean eating with socioeconomic factors and bean-related meanings, material issues and competence. While the appeals for health, morality and environmental protection are having positive effects on the demand for plant-based food, several enterprises or social groups have created a new wave of plant-based food with the help of celebrities, making "vegetarianism" an emerging lifestyle following Lohas. For instance, Stella McCartney, a designer for GUCCI launched a series of high-priced fashion products for vegetarians in 2001, which were endorsed by Natalie Portman, another celebrity vegetarian. PETA holds its annual selection of Sexiest Star of Plant-based Food across the world. Chung-tang Shih (the chairman of ASUSTeK Computer Inc.), Biz Stone (the co-founder and creative director of Twitter), and William Clay Ford, Jr. (the executive chairman of Ford Motor Company) all encourage their employees to consume plant-based food.

\subsection{Consumers' motivation toward involvement}

Involvement can be regarded as a force that triggers consumer motivation and is used to explain the decision-making process of consumers, including the duration of decision-making, as well as the formation of faith, attitude, intention and behavior (Kapferer, 1993). Teng and Lu (2016) revealed that the three main organic food consumption motives included health consciousness, food safety concerns and ecological motives.

\subsection{Involvement toward the attitude}

Michaelidou and Hassan (2010) observed that attitude had a more important role in the effect of food safety concerns regarding the intention to purchase organic produce. Such involvement variables drive consumers to the products that meet with their values, need, or benefits and further stimulate the consumers' purchasing behavior (Teng and Lu, 2016; Jeong and Jang, 2016).

Armstrong, Kolter and Opresnik (2017, p176) defined attitude as "a person's long-term positive or negative comments on, feelings and behavioral tendencies for certain objects or concepts"; it was not only a way of thinking but also triggered a "behavioral tendency." There are diverse factors which influence the formation of consumer attitude. It does not always require careful consideration. Product attitude, however, influences the decision regarding the purchase of products (Lin, 2010;Jeong and Jang,2016). Attitude has a great influence on consumer purchasing behavior. According to Foodwatch (2008), consumers' understanding and knowledge of food quality influenced their attitudes and their subsequent purchasing intentions (Cheah and Phau, 2011; Tenng and $\mathrm{Lu}, 2016$ ).

\subsection{Attitude toward the purchase intention}

According to Bagozzi and Burnkrant (1979), purchase intention refers to a person's behavioral tendency towards products; it is a process where an individual intentionally planned to purchase a brand's products (Spears \& Singh, 2004). Zeithml (1988) introduced the method of measuring purchase intention with cognitive value, which involved the question items, "May purchase", "Want to purchase" and "Consider the purchase". The scale of this paper was based on Zeithml's research and consisted of such items as "Be willing to purchase", "Believe it worthy of purchase", and "Recommend others to purchase."Magnusson et al. (2003) and Chen(2007) suggest health concerns as a strong predictor of attitude and purchase intention.

\section{Research Design}

In this paper, SPSS22.0 was adopted for the statistical analysis. The structural model analysis of the general model of the structural equation was made with AMOS19.0. The research model is shown in Figure 1.Environment Education and Eco-Environmental Protection Art Exhibition Environment Education and Eco-Environmental Protection Art Exhibition

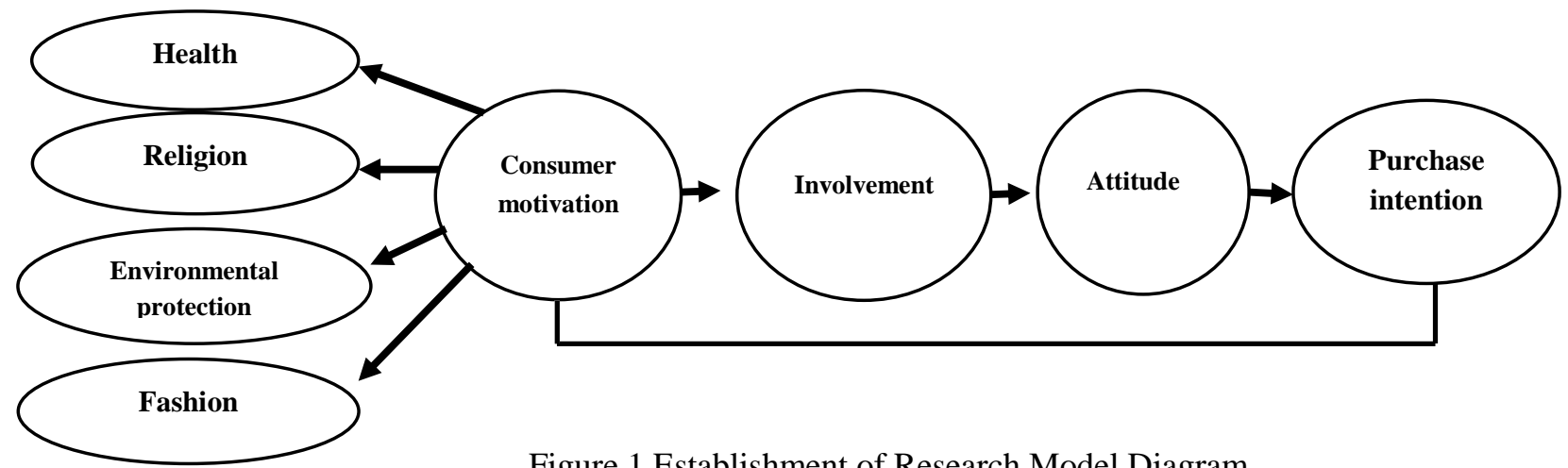

92 
In this paper, reliability and validity analysis, one-way ANOVA, Pearson's product-moment correlation, factor analysis, and structural equation modeling were adopted to test the reliability and consistency of the questionnaire.

\section{Empirical Results}

\subsection{Basic information regarding the young respondents}

There were two questionnaires given in this study. The questionnaire respondents had taken environmental protection courses, and each respondent had received environmental education training which lasted for at least 36 hours, or a semester. Meanwhile, the young respondents of the second questionnaire participated in eco-environmental protection art exhibitions. Most of the respondents consumed meat-based food; and over half of respondents had no religious beliefs. Approximately $90 \%$ of the respondents supported the government's Meatless Monday program. In class, the teacher publicized plant-based food, discussed such topics as climate change and global warming, and expressed the idea that consuming more plant-based food helped reduce $\mathrm{CO}_{2}$ emissions and protect animals. Moreover, a 30-day environmental protection eco-art exhibition was held. According to the empirical results, the respondents' intention to consuming plant-based food increased to the level of 1 to 3 times a week, and the proportion rose from $80.3 \%$ to $91.6 \%$. Most of the young people had a medium level of knowledge regarding plant-based food (see Table 1).

\subsection{Young consumers' consumer motivation, involvement, attitude and purchase intention for plant-based food}

From the perspective of health-base motivation, approximately $90 \%$ of the respondent agrees that plant-base food was beneficial for health. Most religious groups or public interest organizations intend to encourage people to consume more plant-based food in order to protect the environment. However, religion is not a major factor for the young respondents, given the fact that majority of young people do not have strong religious beliefs.

From the angle of environment protection-based motivation, the Intergoverment Panel on Climate Change (IPCC) believes that animal husbandry is one of the sources of $\mathrm{CO}_{2}$ emissions and thus advocates that less meat should be consumed. In the first questionnaire, approximately one third of the consumers were willing to eat plant-based food, and $50 \%$ of the consumers were ready to consume plant-based food to fight against global warming and reduce damage to environment. The results show that the "environmental protection" factor could change people's diet. In the second questionnaire, approximately $70 \%$ of the consumers were willing to accept plant-based food, and $70 \%$ of consumers were ready to consume plant- based food to fight against global warming and reduce damage to the environment. This reveals that the "environmental protection" factor can change people's diet. In terms of marketing strategy, if icons and celebrities are invited to popularize plant-based food, the publicity effect will be limited. The findings of this study show that price and flavor are the main considerations regarding the attitudes of consumers toward plant-based food (see Table 2).

Table 1: Descriptive Statistics and Data

\begin{tabular}{|c|c|c|c|}
\hline Item & \multicolumn{2}{|c|}{$1^{\text {st }}$ Questionnaire Survey } & $2^{\text {nd }}$ Questionnaire Survey \\
\hline Course Period & \multicolumn{2}{|c|}{$\begin{array}{l}\text { From September } 2015 \text { to January } 2016 \\
\text { (Took the environmental protection course and obtained } 2 \text { credits, with a } 36- \\
\text { hour study record) }\end{array}$} & $\begin{array}{l}\text { From February } 2016 \text { to June } 2016 \\
\text { (Took green environment and } \\
\text { economics courses, as well as } \\
\text { marketing, and participated in } \\
\text { publicizing the environmental } \\
\text { protection art activities for a month } \\
(2016 / 03 / 29 \sim 2016 / 05 / 03)\end{array}$ \\
\hline Survey Period & \multicolumn{2}{|l|}{$2016 / 01 / 05 \sim 2016 / 01 / 20$} & $2016 / 06 / 01 \sim 2016 / 06 / 20$ \\
\hline Total Number of Samples & \multicolumn{2}{|l|}{850} & 124 \\
\hline Valid Samples & $\mathrm{n} 1=386$ & $\mathrm{n} 2=237$ & $\mathrm{n} 3=119$ \\
\hline Consumer Motivation & $\begin{array}{l}\text { Health, religion, environmental } \\
\text { protection, and fashion }\end{array}$ & Health and religion & $\begin{array}{l}\text { Health, religion, environmental } \\
\text { protection, and fashion }\end{array}$ \\
\hline Religious Belief & $\begin{array}{l}\text { Buddhism } 19.4 \% \\
\text { Taoism } 20.5 \% \\
\text { unbelievers } 53.1 \% \text {. }\end{array}$ & $\begin{array}{l}\text { Buddhism } 14.3 \% \\
\text { Taoism } 24.1 \% \text {; } \\
\text { unbelievers } 55.3 \% \text {. }\end{array}$ & $\begin{array}{l}\text { Buddhism } 16.0 \% \\
\text { Taoism } 20.2 \% \\
\text { unbelievers } 56.3 \% \text {. }\end{array}$ \\
\hline Meat Eaters & $88.1 \%$ & $89.0 \%$ & $90.8 \%$ \\
\hline Frequency of Consuming Plant-Based Food & $\begin{array}{l}\text { Those who did notconsume any plant- } \\
\text { based food accounted for } 56.5 \% \text {; those } \\
\text { who consumed plant-based food once or } \\
\text { twiceaccounted for } 28.2 \%\end{array}$ & $\begin{array}{l}\text { Those who did notconsume } \\
\text { any plant-based food } \\
\text { accounted for } 58.2 \% \text {; those } \\
\text { who consumed plant-based } \\
\text { food once or twice accounted } \\
\text { for } 29.5 \%\end{array}$ & $\begin{array}{l}\text { Those who did notconsume any plant- } \\
\text { based food accounted for } 46.2 \% \text {; those } \\
\text { who consumed plant-based food once } \\
\text { or twice accounted for } 43.7 \%\end{array}$ \\
\hline $\begin{array}{l}\text { Acceptance of the Government's "Meatless } \\
\text { Monday" }\end{array}$ & $80.3 \%$ & $70.5 \%$ & $91.6 \%$ \\
\hline Understanding of Plant-Based Food & Medium & Medium & Medium \\
\hline
\end{tabular}


Table 2: Young People' Consumer Motivation Regarding Plant-Based Food

\begin{tabular}{|c|c|c|c|c|}
\hline \multicolumn{2}{|r|}{ Item } & \multicolumn{2}{|c|}{$1^{\text {st }}$ Questionnaire Survey } & \multirow{2}{*}{$\begin{array}{l}2^{\text {nd }} \text { Questionnaire } \\
\text { Survey } \\
(n=119)\end{array}$} \\
\hline Number of Samples & & $(n=386)$ & $(n=237)$ & \\
\hline \multirow[t]{4}{*}{ Health-Based Motivation } & $\begin{array}{l}\text { I believe that plant-based food is beneficial for } \\
\text { physical health and can offer adequate nutrition. }\end{array}$ & $94.5 \%$ & $92.5 \%$ & $93.2 \%$ \\
\hline & $\begin{array}{l}\text { I believe that those who consume a lot of meat and } \\
\text { seafood have a higher risk of stroke. }\end{array}$ & $90.7 \%$ & $88.2 \%$ & $83.2 \%$ \\
\hline & $\begin{array}{l}\text { Vegetarians are less likely to suffer hypertension, } \\
\text { heart attack, cancers and diabetes. }\end{array}$ & $69.0 \%$ & $65.0 \%$ & $76.5 \%$ \\
\hline & $\begin{array}{l}\text { I believe that vegetables, fruits and whole grains } \\
\text { would be less likely to cause weight gain and } \\
\text { obesity. }\end{array}$ & $66.7 \%$ & $61.6 \%$ & $77.3 \%$ \\
\hline \multirow[t]{3}{*}{ Religion-Based Motivation } & I believe that taking plant-based food is merciful. & $30.3 \%$ & $26.5 \%$ & $53.0 \%$ \\
\hline & $\begin{array}{l}\text { I believe taking plant-based food is a form of } \\
\text { spirituality. }\end{array}$ & $16.1 \%$ & $15.6 \%$ & $28.6 \%$ \\
\hline & I do not think it is necessary to eat animals. & $17.9 \%$ & $16.4 \%$ & $21.9 \%$ \\
\hline \multirow[t]{4}{*}{$\begin{array}{l}\text { Environmental Protection-Based } \\
\text { Motivation }\end{array}$} & $\begin{array}{l}\text { I know that one of the causes for climate change is } \\
\text { that animal husbandry generates excessive } \\
\text { methane. }\end{array}$ & $83.1 \%$ & -- & $92.4 \%$ \\
\hline & $\begin{array}{l}\text { Consuming more plant-based food can save food } \\
\text { for more people and control the increase in food } \\
\text { price. }\end{array}$ & $43.1 \%$ & -- & $65.5 \%$ \\
\hline & $\begin{array}{l}\text { I am willing to consume plant-based food to fight } \\
\text { against global warming and reduce the damage to } \\
\text { the environment. }\end{array}$ & $43.5 \%$ & -- & $71.4 \%$ \\
\hline & $\begin{array}{l}\text { Consuming plant-based food can promote } \\
\text { sustainable social development. }\end{array}$ & $40.2 \%$ & -- & $68.1 \%$ \\
\hline \multirow[t]{3}{*}{ Fashion-Based Motivation } & I am willing to taste plant-based food. & $43.5 \%$ & -- & $69.7 \%$ \\
\hline & $\begin{array}{l}\text { Consumers want to taste plant-based food because } \\
\text { relevant sales promotionshave been launched in the } \\
\text { catering industry. }\end{array}$ & $50.7 \%$ & -- & $68.1 \%$ \\
\hline & $\begin{array}{l}\text { I would like to taste plant-based food because my } \\
\text { favorite icons and celebrities are consuming plant- } \\
\text { based food. }\end{array}$ & $13.7 \%$ & -- & $26.0 \%$ \\
\hline \multirow[t]{7}{*}{ Involvement } & $\begin{array}{l}\text { I believe that it is important to consume plant- } \\
\text { based food. }\end{array}$ & $45.0 \%$ & -- & $45.3 \%$ \\
\hline & I am interested in plant-based food. & $40.2 \%$ & -- & $47.9 \%$ \\
\hline & $\begin{array}{l}\text { I am willing to consume plant-based food for my } \\
\text { personal health. }\end{array}$ & $59.3 \%$ & -- & $69.8 \%$ \\
\hline & $\begin{array}{l}\text { I believe that consuming plant-based food is } \\
\text { meaningful. }\end{array}$ & $48.2 \%$ & -- & $56.4 \%$ \\
\hline & $\begin{array}{l}\text { I agree that one's personality can be evaluated } \\
\text { through his/her practice of consuming plant-based } \\
\text { food. }\end{array}$ & $19.4 \%$ & -- & $38.6 \%$ \\
\hline & $\begin{array}{l}\text { The practice of consuming plant-based food can } \\
\text { reflect one's personality. }\end{array}$ & $18.4 \%$ & -- & $33.6 \%$ \\
\hline & $\begin{array}{l}\text { I do not think consuming meat-based food by } \\
\text { accident is serious. }\end{array}$ & $67.9 \%$ & -- & $69.0 \%$ \\
\hline \multirow[t]{3}{*}{ Attitude } & $\begin{array}{l}\text { Consuming more plant-based food is good for the } \\
\text { environment and physical health. }\end{array}$ & $77.2 \%$ & $75.6 \%$ & $89.1 \%$ \\
\hline & I enjoy consuming plant-based food. & $61.9 \%$ & $71.3 \%$ & $71.4 \%$ \\
\hline & I agree to consuming plant-based food as a staple. & $32.2 \%$ & $36.7 \%$ & $45.3 \%$ \\
\hline \multirow[t]{3}{*}{ Purchase Intention } & $\begin{array}{l}\text { I am willing to consider living on vegetables and } \\
\text { fruits. }\end{array}$ & $37.6 \%$ & $43.0 \%$ & $49.6 \%$ \\
\hline & I am willing to live on vegetables and fruits. & $33.7 \%$ & $35.0 \%$ & $48.7 \%$ \\
\hline & $\begin{array}{l}\text { I am willing to eat more vegetables and fruits and } \\
\text { recommend them to my friends. }\end{array}$ & $46.1 \%$ & $51.8 \%$ & $63.9 \%$ \\
\hline
\end{tabular}

According to the empirical results, there seems to be no direct correlation between the consumption of plant-based food and personality. In the past, it was believed that the consumption of plant-based food was directly related to religious beliefs and that religious believers typically had good personalities. However, the empirical results show that the assumption is incorrect. Approximately $70 \%$ of the consumers continued to consume meat-based food. Therefore, changing the consumers' eating habits is difficult. Nearly $80 \%$ of the respondents of this study consume meat-based food, but approximately $80 \%$ to $90 \%$ of them agreed that plant-based food was beneficial for environmental protection and health. 
The intention to consume plant-based food in the first questionnaire survey was stronger than that in the second one. Additionally, this study found that the environmental protection curriculum and the environmental protection eco-art exhibitions can deepen young people's understanding of plant-based food and enhance their intention to consume plant-based food. It is clear that the respondents accepted the idea of consuming plant-based food, but it was also observed that there was still a large gap between the expectation and reality.

The findings of this paper also show that environmental protection eco-art activities can motivate young people to accept and popularize plant-based food, in addition to the regular environmental protection education curriculum (see Table 2). The combination of the environmental protection education curriculum and the environmental protection ecoart exhibitions enhanced young people's consumer motivation, involvement and purchase intention and their attitude towards plant-based food.

\subsection{Reliability and validity}

We follow the researchers Cheah and Phau (2011) and DelVecchio (2000), who have suggested that students and a young sample are reliable in such studies. According to the empirical results, the Cronbach's Alpha of reliability of all variables was higher than 0.7 , meeting the requirement on reliability. The total reliability value of the first questionnaire survey was 0.946 , and the second questionnaire was 0.957 .

Table 3: Reliability of Variables in the Questionnaire Surveys

\begin{tabular}{|l|c|c|c|}
\hline Item & \multicolumn{2}{|c|}{$\begin{array}{c}\text { Cronbach's Alpha of the 1 } \\
\text { Questionnaire Survey }\end{array}$} & $\begin{array}{c}\text { Cronbach's Alpha of the 2 } \\
\text { Questionnaire Survey }\end{array}$ \\
\hline Number of Samples & $(\mathrm{n}=386)$ & $(\mathrm{n}=237)$ & $(\mathrm{n}=119)$ \\
\hline Health-Based Consumer Motivation & 0.735 & 0.708 & 0.658 \\
\hline Religion-Based Consumer Motivation & 0.880 & 0.906 & 0.863 \\
\hline $\begin{array}{l}\text { Environmental Protection-Based } \\
\text { Consumer Motivation }\end{array}$ & 0.904 & - & 0.869 \\
\hline Fashion-Based Consumer Motivation & 0.833 & - & 0.898 \\
\hline Involvement & 0.859 & - & 0.904 \\
\hline Toward the Attitude & 0.787 & 0.759 & 0.752 \\
\hline Purchase Intention & 0.883 & 0.862 & 0.917 \\
\hline Total & $\mathbf{0 . 9 4 6}$ & $\mathbf{0 . 9 0 7}$ & $\mathbf{0 . 9 5 7}$ \\
\hline
\end{tabular}

Hair (1977) proposed that a composite reliability of 0.7 was an acceptable threshold. Fornel and Larcker (1981) suggested that composite reliability should be over 0.6 and that the standard average variance extracted must be over 0.5. The empirical results of the questionnaires met the above requirement that composite reliability should be higher than 0.7 and that average variance extracted should be higher than 0.5 (see Table 4)

Table 4: CR and AVE

\begin{tabular}{|l|c|c|c|c|}
\hline \multirow{2}{*}{ Item } & \multicolumn{2}{|c|}{$\mathrm{n=386}$} & \multicolumn{2}{c|}{$\mathrm{n}=119$} \\
\cline { 2 - 5 } & $\begin{array}{c}\text { Composite } \\
\text { reliability }\end{array}$ & $\begin{array}{c}\text { Average variance } \\
\text { extracted }\end{array}$ & $\begin{array}{c}\text { Composite } \\
\text { reliability }\end{array}$ & $\begin{array}{c}\text { Average } \\
\text { variance } \\
\text { extracted }\end{array}$ \\
\hline Health-Based Consumer Motivation & 0.824 & 0.609 & 0.794 & 0.566 \\
\hline Religion-Based Consumer Motivation & 0.939 & 0.792 & 0.881 & 0.650 \\
\hline Religion-Based Consumer Motivation & 0.936 & 0.787 & 0.901 & 0.697 \\
\hline Fashion-Based Consumer Motivation & 0.903 & 0.699 & 0.918 & 0.736 \\
\hline Involvement & 0.931 & 0.774 & 0.937 & 0.789 \\
\hline Toward the Attitude & 0.885 & 0.720 & 0.868 & 0.687 \\
\hline Purchase Intention & 0.927 & 0.809 & 0.947 & 0.857 \\
\hline
\end{tabular}

\subsection{Demographical statistics and consumer motivation}

This finding indicates that nearly $60 \%$ of the young respondents were unbelievers, and $80 \%$ of them consumed meatbased food. According to the empirical results, young people would not consume plant-based food forreligious purposes, and most of them did not have any religious beliefs. However, a greater proportion of young people consumed plant-based food for the sake of environmental protection. As the Taiwanese government has implemented the Meatless Monday program in elementary and middle schools for 10 years, most young people are willing to accept plant-based food, which is reflected in their consumer motivation. This finding also indicates that the government plays an important role in publicizing plant-based food. 


\subsection{Established constructs of the Structural Equation Model (SEM)}

According to the general model evaluation and the estimate of coefficients in the empirical results, most of the evaluation results met the expectation, and the criterion ratio of all dimensions was over 2. Consumer motivation was also observed to influence consumer involvement; the involvement would influence consumer attitude, which would finally influence purchase intention for the plant-based food. The values for CFI are above 0.90 and the RMSEA values are below 0.08 (Hu \& Bentler, 1999). The resultsare provided in Tables 5 and 6 . The models provided are a good fit with $\mathrm{N}=386, \mathrm{CFI}=0.944$, TLI $=0.934$, RMSEA $=0.065$, and $\mathrm{N}=119, \mathrm{CFI}=0.958, \mathrm{TLI}=0.950, \mathrm{RMSEA}=0.054$, according to the usual conventions (Hair et al., 1998; Hu and Bentler, 1999). The results agree with the research by Rambalak and Govind (2016), which observed that the young people's attitude influences the consumers' intention towards purchasing green products.

Table 5: General Model Evaluation of Young Consumers' Intention to Purchase Plant-based Food

\begin{tabular}{|c|c|c|c|c|}
\hline \multirow[t]{2}{*}{ Name } & \multirow[t]{2}{*}{ Evaluation Item } & \multirow{2}{*}{$\begin{array}{l}\text { Expected } \\
\text { Evaluation Result }\end{array}$} & \multicolumn{2}{|c|}{ Results of General Model Evaluation } \\
\hline & & & Model $1 \mathrm{n}=386$ & Model $2 \mathrm{n}=119$ \\
\hline \multirow[t]{10}{*}{$\begin{array}{l}\text { Goodness-of-Fit of General } \\
\text { Mode }\end{array}$} & $\begin{array}{l}\text { Chi-square } \\
\text { value }\end{array}$ & $\mathrm{P} \geqq 0.05$ & 0.000 & 0.000 \\
\hline & $\begin{array}{l}\text { Ratio of Chi- } \\
\text { square value }\end{array}$ & $2 \sim 5$ & 2.623 & 1.349 \\
\hline & GFI & Higher than 0.9 & 0.877 & 0.819 \\
\hline & RMSEA & Less than 0.08 & 0.065 & 0.054 \\
\hline & AGFI & Higher than 0.8 & 0.844 & 0.806 \\
\hline & CFI & Higher than 0.9 & 0.944 & 0.958 \\
\hline & NFI & Higher than 0.9 & 0.912 & 0.857 \\
\hline & IFI & Higher than 0.9 & 0.944 & 0.959 \\
\hline & RMR & Less than 0.05 & 0.125 & 0.105 \\
\hline & TLI & Higher than 0.9 & 0.934 & 0.950 \\
\hline
\end{tabular}

$\mathrm{N}=386$

$\mathrm{CFI}=0.944$

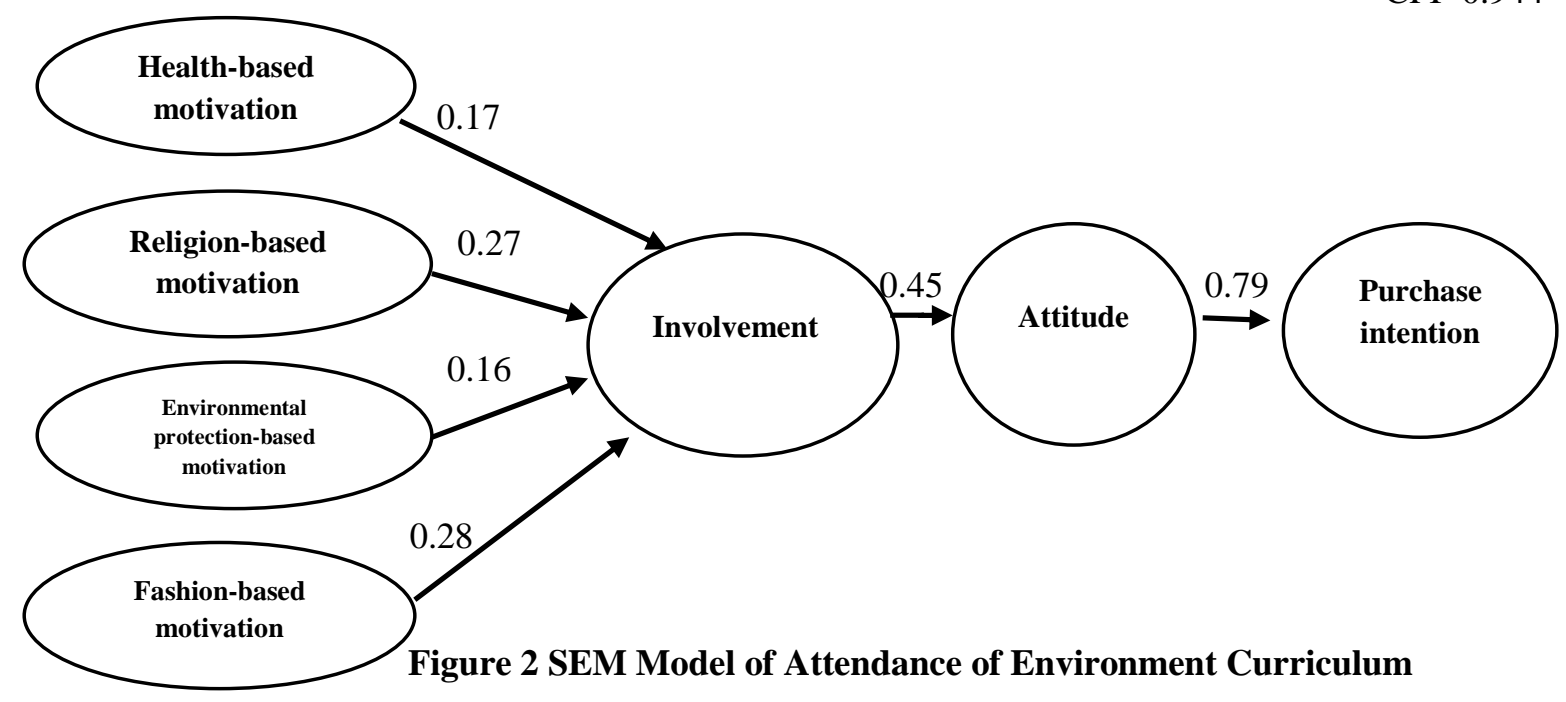


Table 6: Estimates of SEM Coefficients

\begin{tabular}{|c|c|c|c|c|c|c|c|c|}
\hline \multirow[t]{2}{*}{ Item } & \multicolumn{4}{|c|}{$\mathrm{n}=386$} & \multicolumn{4}{|c|}{$\mathrm{n}=119$} \\
\hline & Coefficient & $\begin{array}{l}\text { Standard } \\
\text { deviation }\end{array}$ & Criterion & $\begin{array}{l}\mathrm{P} \text { - } \\
\text { value }\end{array}$ & Coefficient & $\begin{array}{l}\text { Standard } \\
\text { deviation }\end{array}$ & Criterion & P-value \\
\hline $\begin{array}{l}\text { Involvement } \longleftarrow \\
\text { (Health) }\end{array}$ & 0.17 & 0.037 & 4.56 & $* * *$ & -0.05 & 0.063 & -0.72 & 0.47 \\
\hline $\begin{array}{l}\text { Involvement } \longleftarrow \text { } \\
\text { (Religion) }\end{array}$ & 0.27 & 0.037 & 7.23 & $* * *$ & 0.31 & 0.063 & 4.87 & $* * *$ \\
\hline $\begin{array}{l}\text { Involvement } \\
\text { (Environment) }\end{array}$ & 0.16 & 0.037 & 4.48 & $* * *$ & 0.19 & 0.063 & 2.95 & 0.003 \\
\hline $\begin{array}{l}\text { Involvement } \\
\text { (Fashion) }\end{array}$ & 0.28 & 0.037 & 7.66 & $* * *$ & 0.39 & 0.063 & 6.19 & $* * *$ \\
\hline $\begin{array}{l}\text { Attitude } \\
\text { (Involvement) }\end{array}$ & 0.45 & 0.053 & 8.50 & $* * *$ & 0.54 & 0.089 & 6.05 & $* * *$ \\
\hline $\begin{array}{l}\text { Purchase } \\
\text { Intention } \\
\text { (Attitude) }\end{array}$ & 0.79 & 0.032 & 24.57 & $* * *$ & 0.77 & 0.061 & 12.75 & $* * *$ \\
\hline
\end{tabular}

Note: $* * * \mathrm{p}<.001$.

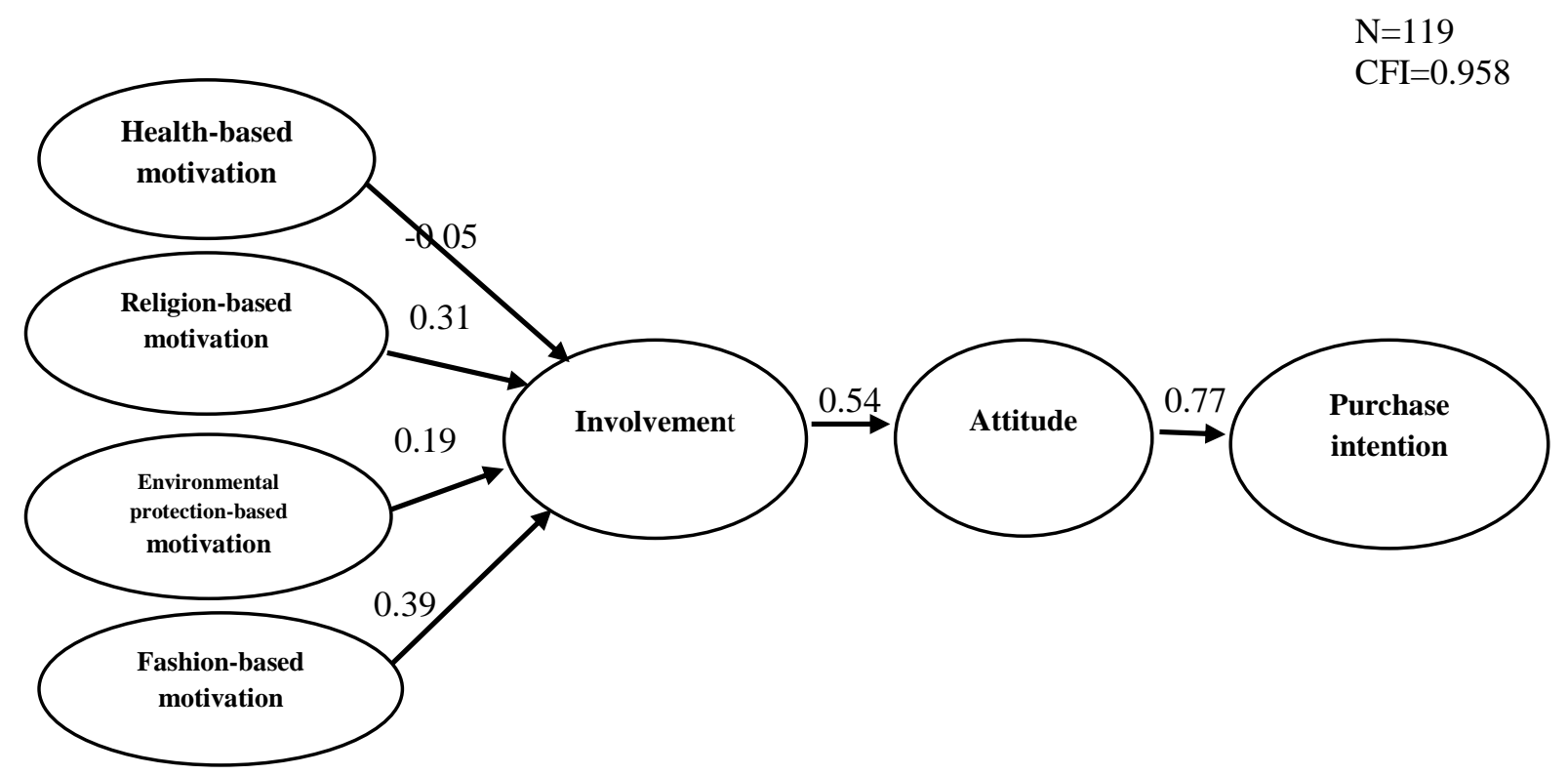

Figure 3 SEM Model of Attendance of Environmental Curriculum and Eco-Environmental Art Exhibition

\section{Conclusions}

To reduce $\mathrm{CO}_{2}$ emissions, the IPCC has advocated consuming more plant-based food. Taiwan's Ministry of Education has implemented the Meatless Monday program in elementary and middle schools. During the 10-year implementation, the government has played an essential role in the popularization of plant-based food. At present, there are 2.5 million vegetarians in Taiwan. According to the empirical results of this study, young consumers have begun to become aware of the importance of longevity preservation, probably because they are still a young generation. In the past, the Taiwanese believed that consuming plant-based food was a posture of mercy, and those who had a religious belief were willing to consume plant-based food. However, at present, there has been an increase in the proportion of people who are willing to consume plant-based food to reduce $\mathrm{CO}_{2}$ emissions and to mitigate environment factors, such as global warming and climate change. Moreover, consuming plant-based food is not necessarily believed to be related to having a good personality, which has also been demonstrated in the empirical study. Such a concept has changed the stereotype that those who consume plant-based food do so based on religious beliefs, mercy or karma.

With the SEM and the survey based on the environment education curriculum and eco-environment art exhibitions, this study explored the change in young people's involvement in consuming plant-based food and their attitude towards it followed by the change to their behavioral intentions from four dimensions - health, religion, environment and fashion. The empirical results show that young people have a medium level of knowledge regarding the consumption of plant- 
based food and that diversified environmental education can encourage young people to pay more attention to the environment and later strengthen their behavioral intention for consuming plant-based food. In addition, young people may change their diet after taking courses regarding environment protection and after participating in eco-art exhibitions. According to the empirical data, consuming plant-based food is beneficial to human health.

\section{References}

Armstrong G.; P. Kotler and Marc O. Opresnik, (2017).Marketing An Introduction,(13th ed.), Pearson Education, Inc.

Anthony J McMichael, John W Powles, Colin D Butler, Ricardo Uauy,(2007). Food, livestock production, energy, climate change, and health, Energy and Health, 5,370,1253-1263.

Ajzen, I., \& Fishbein, M. (1980).Understanding attitudes and predicting social behavior, Englewood Cliffs, NJ: Prentice-Hall.

Bagozzi, R. P., \& Burnkrant, R. E., (1979). Attitude organization and attitude-behavior relationship, Journal of Personality and Social Psychology, 37(1), 913-929.

Cheng Huaxing, Chen Junjie, (2009). Vegetarian environmental protection and the fight against global warming. Taiwan Medical Association, 52 (1), 57-58.

Chen, M.-F., (2007). Consumer attitudes and purchase intentions in relation to organic foods in Taiwan: moderating effects of food-related personality traits. Food Quality and Preference, 18, 1008-1021.

Cheah, I., Phau, I., (2011). Attitudes towards environmentally friendly products: the influence of ecoliteracy, interpersonal influence and value orientation. Marketing Intelligence \& Planning, 29 (5), 452-472.

DelVecchio, D., (2000).Moving beyond fit: the role of brand portfolio characteristics in consumer evaluations of brand reliability. J. Prod. Brand Manag, 9 (7),457-471.

Elin Ro"o"s; Hele'ne Tjärnemo,(2011). Challenges of carbon labelling of food products: a consumer research perspective, British Food Journal, 113, 8, 982-996.

Hair, J.F., Anderson, R.E., Tatham, R.L., Black, W.C., (1998).Multivariate Data Analysis, Prentice Hall International, Hemel Hempstead.

Huang Jianxun (2010). Warming and Medical Science and Ethics. Global Forum on Global Warming and National Health, Taiwan Medical Association, 53 (3), 130-134.

Hu, L. T., \& Bentler, P. M., (1999). Cutoff criteria for fit indexes in covariance structure analysis: conventional criteria versus new alternatives, Structural Equation Modeling A Multidisciplinary Journal, 6(1), 1-55.

Jallinoja, P., Niva, M., Helakorpi, S., \& Kahma, N., (2014). Food choices, perceptions of healthiness and eating motives of self-identified followers of low-carbohydrate diet, Food and Nutrition Research, 58, 1-9.

Jallinoja P., M. Niva \& T.Latvala,(2016).Future of sustainable eating? Examining the potential for Expanding bean eating in a meat-eating culture, Future,1-11.http://dx.doi.org/10.1016/j.futures.2016.03.006

Jeong E.\&S. Jang, (2016).Imagine yourself being healthy: The mental simulation effect of advertisements on healthy menu promotion,International Journal of Hospitality Management, 53, 81-93.

Jessica Aschemann-Witzel,(2015). Consumer perception and trends about health and sustainability: trade-offs and synergies of two pivotal issues, Current Opinion in Food Science, 3,6-10.

Kapferer, J. N and Laurent, G. (1993). Further evidence on the consumer involvement profile:five antecedents of involvement. Psychology and Marketing, 10(4),347-355.

Lin Jian Huang (2010). Consumer Behavior, Taiwan: Huatai publishing Inc.

Lindeman, M., \& Stark, K. (1999). Pleasure, pursuit of health, or negotiation of identity? Personality correlates of food choice motives among young and middle-aged women, Appetite, 33, 141-161.

Lu Junliu, (2006). Religious Festival and Diet - Taking folk beliefs and Judaism for example, Master's thesis of Tzu Chi University Institute of Religion and Culture, Taiwan.

Magnusson, M.K., Avrola, A., Hursti, K.U.-K., Aberg, L., Sjoden, P.-O., (2003). Choice of organic produce is related to perceived consequences for human health and to environmentally friendly behavior, Appetite, 40, 109-117.

Mäkiniemi, J.P., \& Vainio, A., (2014). Barriers to climate-friendly food choices among young adults in Finland, Appetite, 74, 12-19.

Michaelidou N.; \&Louise M. Hassan (2010). Modeling the factors affecting rural consumers' purchase of organic and free-range produce: A case study of consumers' from the Island of Arran in Scotland, UK, Food Policy, $35,130-139$.

Rambalak Y. \& Govind S.P, (2016).Young consumers' intention towards buying green products in a developing nation: Extending the theory of planned behavior, Journal of Cleaner Production, 135, 732-739. 
Salleh M. M.,S. M. Ali;E. H.Harun;M. A.Jalil;M. R.Shaharudin , (2010). Consumer's Perception and Purchase Intentions Towards Organic Food Products: Exploring Attitude Among Academician, Canadian Social Science, $6(6), 119-129$.

Schleenbecker, R., \& Hamm, U. (2013). Consumers' perception of organic product characteristics A review, Appetite, 71, 420-429.

Spears, N., \& Singh, S. N. (2004). Measuring attitude toward the brand and purchase intentions, Journal of Current Issues and Research in Advertising, 26(2), 53-66.

Teng C.C,\& C.H.Lu, (2016).Organic food consumption in Taiwan: Motives, involvement, and purchase intention under the moderating role of uncertainty,Appetite, 105, 95-105.

Timothy J. Key, Paul N. Appleby and Magdalena S. Rosell,(2006).Health effects of vegetarian and vegan diets, Plant foods and public health, 65,35-41.

Turner-McGrievy GM, Barnard ND, Cohen J, Jenkins DJ,Gloede L, (2015).Randomization to plant-based dietary approaches leads to larger short-term improvements in Dietary Inflammatory Index scores and macronutrient intake compared with diets that contain meat, Nutrition Research, 35, 97-106.

Tu Zongcheng, (2005). Chinese ancient concept of vegetables, National Taiwan University Institute of History Master's thesis, Taiwan.

Vainio A., M. Niva,,P. Jallinoja, T. Latvala, (2016). From beef to beans: Eating motives and the replacement of animal proteins with plant proteins among Finnish consumers, Appetite, xxx, 1-9.

Vermeulen SJ, Campbell BM, Ingram, John SI, (2012). Climate change and food systems, Annual Rev Environ Resource, 37,195-222.

Zeithaml, V. A. (1988). Consumer perceptions of price, quality, and value: a means-end model and synthesis of evidence, The Journal of Marketing, 52 (3), 2-22.

Provisional Statement on Status of Climate in 2013: Continuing high temperatures globally and many climate extremes worldwide. http://www.wmo.int/pages/mediacentre/press_releases/pr_981_EN.html 